ROCZNIKI KULTUROZNAWCZE

Tom XI, numer $1 \quad-\quad 20 \quad 20$

DOI: http://dx.doi.org/10.18290/rkult.2020.11.1-4

WITOLD REPETOWICZ

\title{
WPŁYW NIEZRÓWNOWAŻONEGO PRZYROSTU NATURALNEGO W POŁUDNIOWYM SĄSIEDZTWIE EUROPY NA WYSTĘPOWANIE KONFLIKTÓW WEWNĘTRZNYCH I REGIONALNYCH
}

\begin{abstract}
WSTĘP
Niezrównoważony przyrost naturalny $\mathrm{w}$ Afryce i na Bliskim Wschodzie będzie rodzić negatywne skutki społeczne i polityczne zarówno w wymiarze wewnętrznym, jak i zewnętrznym. Chodzi przy tym zarówno o niezrównoważenie wewnętrzne, polegające na zróżnicowanym przyroście między różnymi grupami w jednym państwie lub między kilkoma państwami regionu, jak i niezrównoważenie między tym makroregionem a Europą. Potencjał demograficzny może przy tym determinować potęgę państwa i wpływać na zmianę regionalnego układu sił. To jednak potęguje zagrożenie konfliktu, w tym o charakterze zbrojnym, zwłaszcza jeśli państwo to nie jest zdolne do zagospodarowania nowych roczników wchodzących w wiek produkcyjny poprzez tworzenie nowych miejsc pracy i rozwijanie perspektyw kariery zawodowej poprzez rozwój edukacji. W takiej sytuacji wzrasta prawdopodobieństwo niekontrolowanego buntu młodego pokolenia, a w warunkach złożonej struktury etnicznej, plemiennej lub religijnej - wojny domowej i rozwoju ruchów partyzanckich. Dla zagrożonego wewnętrznymi perturbacjami państwa optymalnym rozwiązaniem może wydawać się wówczas wykorzystanie nadwyżki potencjału demograficznego w otwartej wojnie lub ataku bronią „D” (strumieniem demograficznym) ${ }^{1}$.
\end{abstract}

\footnotetext{
Mgr Witold RePetowicz — ekspert do spraw Bliskiego Wschodu, terroryzmu i geopolityki, absolwent Wydziału Prawa i Administracji Uniwersytetu Jagiellońskiego oraz doktorant na Wydziale Bezpieczeństwa Narodowego Akademii Sztuki Wojennej; adres do korespondencji - e-mail: witold. repetowicz@gmail.com. ORCID: https://orcid.org/0000-0001-8112-5371.

${ }^{1}$ Pojęcie broni demograficznej zostało zdefiniowane w artykule: Witold REPETOWICZ, „Broń 'D' jako zagrożenie asymetryczne", Wiedza Obronna 2018, nr 1-2 (262-263): 107-125. W tym artykule
} 


\section{WPŁYW DEMOGRAFII \\ NA RYWALIZACJĘ O POTĘGĘ NA BLISKIM WSCHODZIE}

W realistycznym paradygmacie stosunków międzynarodowych pojęcie potęgi jest kategorią fundamentalną, determinującą działania państw jako aktorów w tych stosunkach. Jak wskazuje Marcin Kaczmarski ${ }^{2}$, „w realistycznej wizji świata potęga zajmuje dominującą pozycję w stosunkach międzynarodowych" oraz ,jest ona funkcją możliwości danego aktora oraz innych uczestników stosunków międzynarodowych". Zgodnie z tym paradygmatem istotą stosunków międzynarodowych jest nieustanna rywalizacja o potęgę między poszczególnymi państwami. Jak pisze Mirosław Sułek ${ }^{3}$, „potęga w skali świata jest zawsze równa $100 \%$ ”, co oznacza, że „zmagania o potęgę są grą o sumie zerowej, co oznacza, że korzyść jednej strony jest stratą drugiej strony”. Potęga w znaczeniu ogólnym jest ,syntetycznym wyrażeniem zdolności do działań zbiorowych określonej liczby ludności w czasie i przestrzeni”, ${ }^{4}$ a John G. Stoessinger stwierdza: „potęga w stosunkach międzynarodowych to zdolność państwa do użycia swych materialnych i niematerialnych zasobów w sposób, który wpłynie na zachowanie innych państw"5. Wszystkie te definicje bezpośrednio lub pośrednio wskazują rolę czynnika demograficznego, gdyż jest on kluczowym „zasobem naturalnym” każdego państwa. Potęga państwa składa się przy tym z potęgi gospodarczej, wojskowej i geopolitycznej oraz militaryzacji jako pochodnej tych wartości ${ }^{6}$. Składową każdej z tych wartości jest przy tym czynnik demograficzny. $\mathrm{Na}$

przez „strumień migracyjny” rozumie się dużą, zorganizowaną grupę cywilów, usiłującą nielegalnie przekroczyć granice, która jest wykorzystywana przez jedno państwo do negatywnego oddziaływania na inne państwo lub państwa. Wspomniana grupa nie odgrywa przy tym roli podmiotu atakującego i nie jest istotne nawet to, czy ma świadomość udziału w takim ataku.

${ }^{2}$ Marcin KacZMARSKI, „Realizm neoklasyczny”, w: Teorie i podejścia badawcze w nauce o stosunkach międzynarodowych, red. Ryszard Zięba, Stanisław Bieleń i Justyna Zając (Warszawa: Wydział Dziennikarstwa i Nauk Politycznych Uniwersytetu Warszawskiego, 2015), 17.

${ }^{3}$ Mirosław SuŁEK, „Globalny układ sił - stan obecny i kierunki ewolucji”, w: Studia nad geopolityka XX wieku, red. Piotr Eberhardt, seria: Prace Geograficzne nr 242 (Warszawa: IGiPZ PAN, 2013), 85

${ }^{4}$ Robert BiaŁoskórski, Robert Kobryński, Mirosław SuŁeK, Potęga państw 2017. Międzynarodowy uktad sit w procesie zmian. Raport potęgometryczny (Warszawa: Oficyna Wydawnicza AspraJR, 2017), 11

${ }^{5}$ John G. Stoessinger, The Might of Nations: World Politics in Our Times, $3^{\text {rd }}$ edition (New York: Random House, 1969). 27. Więcej na temat definicji potęgi ogólnej zob. SuŁEK, Mirosław. „O potęgonomii i potęgometrii”. Nowa Geopolityka, dostęp 24.05.2020, https://geopolityka.net/opotegonomii-i-potegometrii/.

${ }^{6}$ Mirosław SuŁEK, Potegometria, t. 1 (Warszawa: Europejskie Centrum Analiz Geopolitycznych, 2017). 
potęgę gospodarczą składa się bowiem PKB, czynnik demograficzny (liczba ludności) oraz przestrzenny (powierzchnia terytorium) ${ }^{7}$. Jeśli prześledzimy ranking państw według $\mathrm{PKB}^{8}$, to w pierwszej dziesiątce najsilniejszych gospodarek świata znajdują się cztery państwa, które równocześnie są w pierwszej dziesiątce państw o największej populacji, a trzy kolejne znajdują się w drugiej dziesiątce. $Z$ drugiej strony spośród dziesięciu krajów o największej populacji siedem jest $\mathrm{w}$ grupie dwudziestu państw o najwyższym PKB. Pozostałe trzy kraje, tj. Nigeria, Pakistan i Bangladesz, znajdują się jednak dopiero na odpowiednio 30, 39 i 41 miejscu $^{9}$. Wartość PKB nie determinuje przy tym stopnia zamożności i rozwoju społecznego danego państwa, a jedynie siłę gospodarki. Silna gospodarka determinuje pozycję międzynarodową państwa, gdyż wpływa również na możliwości obronne, ale nie chroni go przed perturbacjami wewnętrznymi, jeśli towarzyszy jej niezdolność do umiejętnego wykorzystania czynnika demograficznego. Również potęga wojskowa państwa zależy m.in. od czynnika demograficznego, tj. liczby żołnierzy powołanych do służby czynnej. Jak piszą Robert Białoskórski, Łukasz Kiczma i Mirosław Sułek w cytowanym opracowaniu, „na potęgę wojskową składają się czynniki wojskowo-ekonomiczne (wydatki wojskowe, będące częścią PKB), czynniki demograficzno-wojskowe (liczba żołnierzy służby czynnej) oraz czynniki przestrzenne (powierzchnia terytorium)". Według rankingu Global Firepower za rok $2019^{10}$ cztery największe potęgi wojskowe znajdują się w pierwszej dziesiątce krajów o największej populacji. Znów jednak nie jest to czynnik automatycznie determinujący siłę militarną, o czym świadczy to, że trzy państwa z pierwszej dziesiątki najludniejszych znajdują się na dalekich miejscach w rankingu militarnym (Meksyk - 34, Nigeria 44, Bangladesz - 45). Potęga geopolityczna jest natomiast pochodną pozostałych dwóch potęg, będąc „średnią arytmetyczną potęgi gospodarczej oraz podwojonej potęgi wojskowej" ${ }^{\prime 1}$.

\footnotetext{
${ }^{7}$ Robert BiaŁoskórski, Łukasz Kiczma i Mirosław SuŁek, Potęga państw 2019. Rankingi potegometryczne (Warszawa: Oficyna Wydawnicza Aspra-JR, 2019).

${ }^{8} \mathrm{Na}$ podstawie danych Banku Światowego za rok 2018, dotyczących nominalnego PKB: The World Bank. Data, dostęp: 25.05.2020, https://data.worldbank.org/indicator/NY.GDP. MKTP.CD? year_high_desc=true. Dalej w niniejszym artykule, o ile nie zaznaczono inaczej, dane dotyczące PKB poszczególnych państw i ich miejsca w rankingu państw pod względem PKB oparte są na tym źródle.

${ }^{9}$ Wszystkie dane podawane w niniejszym artykule dotyczące populacji poszczególnych państw na podstawie danych ONZ: Worldometer. Population, dostęp 27.12.2019. https://www.worldometers. info/population/ Jeśli nie zaznaczono, którego roku dotyczą, oznacza, że odnoszą się do $2019 \mathrm{r}$.

${ }_{10}$ „Global Firepower 2020”, GFP. Strench in Numbers, dostęp 27.12.2019, https://www.global firepower.com/.

${ }^{11}$ Bialoskórski, Kiczma i SuŁek, Potęga państw 2019.
} 
Powyższa analiza ma kluczowe znaczenie dla oceny stabilności regionalnej w najbliższym otoczeniu Europy, w szczególności na Bliskim Wschodzie. Występują tam bowiem istotne nierówności w przyroście demograficznym, a także $\mathrm{w}$ rozwoju społecznym, zamożności oraz zachodzą procesy zmieniające pozycję poszczególnych państw w rankingach potęgometrycznych. Wszystkie te procesy mogą determinować zarówno konflikt wewnętrzny, jak i zewnętrzny. Ten pierwszy może być przede wszystkim efektem spotęgowania niezadowolenia społeczeństwa jednego państwa $\mathrm{z}$ sytuacji ekonomicznej w wyniku jej porównania $\mathrm{z}$ poziomem życia $\mathrm{w}$ krajach sąsiednich. Zwykle przy tym państwa o wyższym poziomie życia na Bliskim Wschodzie są zarazem państwami, których relatywnie niewielka populacja wyłącza je z rywalizacji o potęgę geopolityczną (np. Kuwejt, Bahrajn), chyba że osiągają ją poprzez budowy systemu sojuszników w krajach o większych populacjach (w szczególności dotyczy to Zjednoczonych Emiratów Arabskich i Kataru, wykorzystujących do tego celu zarówno sojuszników państwowych, jak i niepaństwowe i ponadpaństwowe organizacje ${ }^{12}$ ). Wzrost prawdopodobieństwa konfliktu zewnętrznego może z kolei wynikać z tzw. pułapki Tukidydesa, czyli zderzenia wschodzącego mocarstwa z dotychczasowym mocarstwem.

\section{KORELACJA WYSOKIEGO PRZYROSTU NATURALNEGO I NIESTABILNOŚCI}

Analizując sytuację szesnastu krajów Bliskiego Wschodu (włączając Egipt, Iran oraz Turcję, a także licząc oddzielnie Palestynę i Izrael), można zauważyć, że występują duże różnice pod względem przyrostu naturalnego między poszczególnymi państwami, a duży wzrost potencjału demograficznego występuje przede wszystkim w krajach wewnętrznie niestabilnych i o niskiej zamożności społeczeństwa oraz rozwoju społecznym (Palestyna, Irak, Syria, Jemen, a także Egipt). Najczęściej stosowanymi wskaźnikami w tym zakresie są przy tym PKB per capita z uwzględnieniem parytetu siły nabywczej (PPP) oraz wskaźnik rozwoju społecznego (HDI).

\footnotetext{
${ }^{12}$ Chodzi o tzw. proxy, czyli sojuszników wykorzystywanych w konfliktach zastępczych, tj. gdy podmiot uczestniczący w danym konflikcie realizuje interesy państwa trzeciego, niebiorącego formalnie udziału w tym konflikcie. Takim sojusznikiem Zjednoczonych Emiratów Arabskich jest np. Southern Transitional Council w wojnie w Jemenie albo Libijska Armia Narodowa w wojnie w Libii. Sojusznikiem Kataru jest natomiast Bractwo Muzułmańskie jako organizacja ponadpaństwowa i jej poszczególne odłamy, np. w Libii, a także różne ugrupowania dżihadystyczne w Syrii.
} 
Trzema krajami o największych populacjach są Egipt $(101 \mathrm{mln})$, Turcja (84 mln) i Iran $(83,5 \mathrm{mln})$, przy czym w ciągu ostatnich sześćdziesięciu lat ludność Turcji wzrosła o 204\%, Iranu o $278 \%$, a Egiptu o $281 \%$. Te różnice mogą się wydawać stosunkowo niewielkie, ale o ile w Turcji i Iranie można zaobserwować obecnie stagnację demograficzną (i takie są też prognozy), to w Egipcie wskaźniki determinujące przyrost naturalny są wciąż wysokie. $\mathrm{Na}$ przykład współczynnik dzietności w Egipcie wynosi 3,43, w Turcji - 2,11, a w Iranie - 1,96. Powoduje to, że według prognoz liczba ludności Egiptu wzrośnie do 2035 r. o 29\%, Iranu - o 15,5\%, Turcji zaś tylko o $10 \%$. W Turcji występuje jednak duże zróżnicowanie między przyrostem naturalnym wśród etnicznych Turków i Kurdów, na korzyść tych drugich, co dodatkowo będzie osłabiać zdolność kształtowania potęgi tego państwa w oparciu o czynnik demograficzny.

Wszystkie trzy państwa aspirują do roli regionalnych mocarstw. Egipt znajduje się jednak dopiero na 43 miejscu pod względem PKB i na 99 pod względem PKB per capita ${ }^{13}$, a na liście rozwoju społecznego (HDI) dopiero na 116 miejscu $^{14}$. Iran był natomiast na 65 miejscu HDI ${ }^{15}$, Turcja na 59, natomiast pod względem PKB per capita odpowiednio na 62 i 51 miejscu, wreszcie pod względem PKB na 27 i 19. Według rankingu potęgometrycznego ${ }^{16}$ Iran znajduje się obecnie na 15 miejscu największych potęg geopolitycznych, prześcigając zarówno Turcję (20 miejsce), jak i Egipt (30 miejsce). Wysoką pozycję Iranu determinuje przede wszystkim jego potęga wojskowa (12 miejsce), co ma istotne znaczenie ze względu na gwałtowny spadek potęgi gospodarczej tego kraju po wprowadzeniu sankcji. Zmiany demograficzne mogą jednak spowodować stopniowe przesuwanie się Egiptu w tym rankingu.

Te trzy kraje nie wyczerpują jednak listy krajów aspirujących do roli potęg. Pod względem demograficznym istnieje jednak obecnie przepaść między pierwszą trójką a kolejnymi państwami. Czwarte miejsce zajmuje obecnie Irak z 40-milionową populacją, piąte Arabia Saudyjska z 34-milionową,

\footnotetext{
${ }^{13}$ Dane dotyczące PKB per capita na podstawie danych Banku Światowego za rok 2018, $\mathrm{z}$ uwzględnieniem parytetu nabywczego (PPP): The World Bank. Data, dostęp: 25.05.2020, https://data. worldbank.org/indicator/NY.GDP.PCAP.PP.CD?year_high_desc $=$ true.

${ }^{14}$ Dane HDI za rok 2018 (raport UNDP z 2019 r.): United Nations Development Programme. Human Development Reports, dostęp 25.05.2020, http://hdr.undp.org/en/content/2019-human-deve lopment-index-ranking

${ }^{15}$ Należy mieć na uwadze to, że dane za rok 2018 dotyczą okresu przed ponownym nałożeniem na Iran sankcji przez administrację Donalda Trumpa, co może mieć wpływ na obniżenie wartości HDI.

${ }^{16}$ Bialoskórski, Kiczma i Sulek, Potega państw 2019.
} 
a szóste Jemen z 30-milionową. Irak oraz Jemen mają jednak znacznie wyższe wskaźniki determinujące przyrost naturalny i prognozuje się, że populacja Iraku wzrośnie do 2035 r. do $55 \mathrm{mln}$, a do 2050 r. do $71 \mathrm{mln}$, natomiast populacja Jemenu odpowiednio do 36,5 i $48 \mathrm{mln}$. Z kolei w Arabii Saudyjskiej przyrost ten będzie nieznaczny — odpowiednio do 41 i 44,5 $\mathrm{mln}$. Zarówno Irak, jak i Arabia Saudyjska są przy tym krajami, które również aspirują do roli regionalnych mocarstw. We wspomnianym rankingu potęg geopolitycznych Irak znajduje się na 32 miejscu (przed Egiptem), natomiast w rankingu potęg wojskowych znajduje się na 19 miejscu (przed Turcją). Warto przy tym podkreślić, że potęga wojskowa nie jest tożsama z faktyczną siłą militarną danego państwa, ale oznacza raczej jego potencjalne możliwości, których zdolność wykorzystania zależy od czynników politycznych. Potencjał Iraku będzie się zwiększać wraz ze wzrostem jego pozycji demograficznej, co będzie powodować reakcję pozostałych potęg, by poprzez destabilizację polityczną osłabić zdolność tego kraju do wykorzystania swojej potęgi we wzajemnej rywalizacji.

Bliski Wschód jest obecnie regionem ogarniętym licznymi konfliktami, przybierającymi formę wojen domowych i zastępczych. Można przy tym zaobserwować, że państwa o wysokim przyroście naturalnym są areną rywalizacji państw o relatywnie niskim przyroście ludności, co prowadzi do wykluczenia tych pierwszych z rywalizacji o potęgę ${ }^{17}$. W tym kontekście można w szczególności wymienić wojny o charakterze domowo-zastępczym ${ }^{18}$ w Syrii i Libanie, a w Afryce Północnej również w Libii. W kontekście wpływu czynnika demograficznego na rywalizację o potęgę, a także potencjalnej destabilizacji i konfliktów wewnętrznych w omawianym makroregionie, jak też ich potencjalnego wpływu na bezpieczeństwo Europy na szczególną uwagę zasługuje sytuacja Iraku oraz wpływ nierozwiązanych problemów politycznych, takich jak kwestia kurdyjska i palestyńska. Wynika to z roli tych problemów (kurdyjskiego, palestyńskiego i stabilności Iraku) w układzie geopolitycznym Bliskiego Wschodu oraz bezpieczeństwa globalnego ${ }^{19}$.

\footnotetext{
${ }^{17}$ Oczywiście w tych konfliktach kluczową rolę odgrywają również mocarstwa spoza regionu, w niniejszym artykule zostaje to jednak pominięte, gdyż wykracza poza jego temat.

${ }^{18}$ Te wojny mają zasadniczo charakter domowy, ale jednocześnie strony konfliktu wewnętrznego występują jako proxy innych państw, tj. działają również w ich interesie.

${ }^{19}$ Chodzi m.in. o wpływ na globalny terroryzm, a także przenoszenie regionalnych konfliktów bliskowschodnich do Europy w wyniku migracji ludności (w szczególności dotyczy to relacji kurdyjsko-tureckich w Niemczech i aktywności w Europie ekstremalnych organizacji typu Szare Wilki, Osmanen Germania czy PKK).
} 


\section{IRAK - MIĘDZY WSCHODZĄCA POTĘGA A OFIARĄ DESTABILIZACJI}

Szczególne znaczenie ma sytuacja Iraku, który jest areną rywalizacji Arabii Saudyjskiej, Iranu i Turcji, a jednocześnie ma własny potencjał gospodarczy i militarny, zwłaszcza zaś demograficzny, determinujący ewentualne przejście z roli przedmiotu do roli podmiotu takiej rywalizacji. Po Egipcie Irak jest największym pod względem populacji krajem arabskim w tym regionie i jednocześnie drugim po Iranie krajem szyickim. Jeśli chodzi o tę drugą kwestię, to rola Iraku będzie rosła wraz ze zmniejszaniem się różnicy między liczebnością populacji obu krajów. Już obecnie można przy tym zaobserwować rosnącą rywalizację o przywództwo religijne w świecie szyickim między irackim Nadżafem a irańskim Qom. Historia relacji między obydwoma państwami jest przy tym bardzo złożona. W VIII wieku n.e. Iran został podbity przez Arabów ${ }^{20}$, niemniej w późniejszych stuleciach, aż do XVII wieku, Irak znajdował się wielokrotnie pod kontrolą Irańczyków, a pamięć wojny iracko-irańskiej, stoczonej w latach 1980-1988, jest wciąż świeża. Po 2003 r. ponownie to Irak znalazł się pod coraz większymi wpływem Iranu.

Rosnący potencjał Iraku, determinowany m.in. demografią, prowadzi zatem do wzrostu prawdopodobieństwa włączenia się tego kraju w regionalną rywalizację, co z kolei prowadzi do przeciwdziałania krajów broniących swojej pozycji. Efektem jest destabilizacja wewnętrzna Iraku jako wynik stymulacji konfliktów o charakterze zastępczym. Chodzi przede wszystkim o:

1) sektariański konflikt sunnicko-szyicki związany z rywalizacją saudyjsko-irańską,

2) wewnętrzny konflikt szyicki, którego wyrazem są krwawe protesty od jesieni 2019 r., będący rezultatem sporu między zwolennikami tworzenia sojuszu z Iranem w oparciu o szyicką tożsamość a przeciwnikami akcentującymi etniczne różnice persko-arabskie,

3) etniczny konflikt kurdyjsko-arabski, będący częścią większego problemu kurdyjskiego, w który obok Iraku zaangażowany jest zarówno Iran, jak i Turcja, a także Syria.

\footnotetext{
${ }^{20} \mathrm{O}$ tym, jakie znaczenie mają wydarzenia z VII i VIII wieku dla współczesnych relacji iracko-irańskich, świadczy posługiwanie się związaną z tym symboliką. Na przykład wzniesione przez Saddama Husajna po wojnie z Iranem „Miecze Kadisiji” w Bagdadzie nawiązują do bitwy pod Kadisiją, kluczowej dla podboju Iranu z terytorium Iraku. Również Państwo Islamskie posługiwało się określeniami i symboliką nawiązującą do wydarzeń z pierwszego stulecia islamu w celu wzniecania w Iraku wrogości wobec szyitów i Irańczyków.
} 


\section{INNE NEGATYWNE SKUTKI \\ NIEZRÓWNOWAŻENIA DEMOGRAFICZNEGO}

Istnieją jeszcze inne czynniki determinujące konflikty wewnętrzne w krajach o bardzo wysokim przyroście ludności, a także potencjalne międzypaństwowe konflikty w tym regionie. Kraje o wysokim przyroście naturalnym są zwykle owładnięte korupcją i mają nieefektywny system władzy, koncentrujący się na aparacie represji, a nie na rozwoju gospodarczym, tworzeniu nowych miejsc pracy, rozwoju edukacji i stwarzaniu perspektyw dla młodych ludzi. To z kolei powoduje nie tylko marnowanie potencjału demograficznego w wymiarze gospodarczym i generowanie permanentnych problemów społecznych. W Egipcie bezrobocie w przedziale wiekowym 1524 lat sięga $35 \%^{21}$, w Iraku $-36 \%^{22}$, podczas gdy mediana wieku w obu krajach wynosi odpowiednio 24,5 oraz 20 lat. W Sudanie w 2018 r. bezrobocie wśród młodzieży wynosiło $27 \%$, a w Algierii $29 \%$ - i był to jeden z ważniejszych czynników, które spowodowały wybuch rewolucji w 2019 r. i usunięcie tamtejszych dyktatorów: Omara al-Baszira oraz Abdelaziza Butefliki. Warto dodać, że w 43-milionowym Sudanie mediana wieku wynosi 19 lat, a współczynnik dzietności to 4,7 , natomiast przyrost naturalny wynosi 2,42\%. W Algierii wskaźniki te są mniej korzystne dla rozbudowy potencjału demograficznego, ale wciąż są relatywnie wysokie - współczynnik dzietności 2,98, a przyrost ludności 1,95\%.

Problemy ekonomiczne wpływają również na powstawanie innych kwestii społecznych, a mianowicie problemów z zawieraniem małżeństw. Wynika to, po pierwsze, $\mathrm{z}$ regulacji społecznych związanych z kosztem małżeństwa dla rodzin obu stron, po drugie zaś z nadwyżki populacji kobiet przy utrzymującej się praktyce poligamii. Na przykład w Iranie średni wiek mężczyzny zawierającego małżeństwo wynosi obecnie 27,4 lat i wzrósł o trzy lata w ciągu czterech dekad ${ }^{23}$. Potencjalnie może to wpływać na obniżenie przyrostu naturalnego, choć zależy to bardziej od wieku kobiet wstępujących w związek małżeński. Bardziej bezpośrednim efektem tego zjawiska jest to,

${ }^{21}$ „Egypt: Youth unemployment rate from 1999 to 2019”, Statista, dostęp 27.12.2019, https:// www.statista.com/statistics/811968/youth-unemployment-rate-in-egypt/.

22 „Jobs in Iraq: a primer on job creation in the short-term”, The World Bank, dostęp 27.12.2019, http://documents.worldbank.org/curated/en/255111529495871846/pdf/Jobs-in-Iraq-a-primer-on-jobcreation-in-the-short-term.pdf.

23 „Average marriage age in Iran increased by 3 years", Tehran Times, Iran's Leading International Daily, dostęp 27.12.2019, https:/www.tehrantimes.com/news/424338/Average-marriageage-in- Iran-increased-by-3-years. 
że miliony młodych mężczyzn pozostają bez pracy, bez rodziny i bez jakichkolwiek perspektyw. Są oni dla władz problemem, tykającą bombą zegarową, która może zostać jednak wykorzystana w celach militarnych lub skłoniona do migracji do Europy. W tym drugim przypadku może to być naturalny ruch migracyjny lub też świadoma stymulacja dokonana przez władze określonego państwa (strumień migracyjny), mająca na celu destabilizację innych państw lub pozbycie się niekorzystnych grup z własnego terytorium w celu zmiany geografii demograficznej. Na przykład w 2015 r. Turcja odegrała kluczową rolę w wywołaniu kryzysu migracyjnego w Europie.

\section{ZRÓŻNICOWANIE WEWNĘTRZNE PRZYROSTU NATURALNEGO A PROBLEM KURDYJSKI I PALESTYŃSKI}

W przypadku niektórych państw dodatkowym problemem związanym z przyrostem naturalnym jest jego zróżnicowanie wewnętrzne w zależności od grupy etnicznej lub religijnej. Wiąże się to m.in. z dwoma nierozwiązanymi problemami regionu Bliskiego Wschodu, tj. problemem kurdyjskim i palestyńskim. W przypadku tego pierwszego szczególne znaczenie ma fakt znacznie wyższego przyrostu naturalnego wśród ludności kurdyjskiej w Turcji w porównaniu z ludnością etnicznie turecką ${ }^{24}$. Według niektórych prognoz Kurdowie mogą stać się w Turcji większością w trakcie jednego pokolenia. Taki pogląd wyraził między innymi turecki prezydent Recep Tayyip Erdoğan, wzywając etnicznych Turków do przeciwdziałania tej tendencji. Możliwe są przy tym trzy strategie niwelowania tej niekorzystnej dla Turków tendencji demograficznej: zaostrzenie turkifikacji (co w XX wieku okazało się tylko częściowo skuteczne), zwiększenie prokreacji etnicznych Turków (co na razie nie przynosi rezultatów) lub próba zmuszenia Kurdów do emigracji do Europy. Zaostrzenie polityki antykurdyjskiej przez Turcję może jednak spowodować wykorzystanie karty kurdyjskiej przez inne kraje regionu, zwłaszcza te, w których pozycja Kurdów będzie uregulowana. Jest to

\footnotetext{
${ }^{24}$ Ze względu na brak oficjalnych danych dotyczących przyrostu naturalnego w odniesieniu do grup etnicznych w Turcji nie jest możliwe dokładne oszacowanie tych wartości. W 2003 r. jednak współczynnik dzietności ludności tureckojęzycznej wynosił 1,88, a dla kurdyjskojęzycznej - 4,07. Ponadto w 2013 r. we wschodniej Turcji (w której znajdują się tereny rdzennie kurdyjskie) współczynnik dzietności wynosił 3,41, podczas gdy wartość ogólnoturecka była na poziomie 2,11. Dane na podstawie: Ismet Koc, Alanur ÇAVlin i Attila Hancioglu, „Demographic differentials and demographic integration of Turkish and Kurdish populations in Turkey”, Population Research and Policy Review 27 (2008), no. 4: 447-457. DOI: 10.1007/s11113-008-9072-y.
} 
przede wszystkim szansa na wzmocnienie pozycji geopolitycznej Iraku. Warto przy tym dodać, że populacja kurdyjska wzrosła od lat sześćdziesiątych z ok. 6-7 mln do $35 \mathrm{mln}$, a do 2050 r. może wzrosnąć do poziomu 60-70 mln, co będzie stanowić ogromny potencjał demograficzny, mogący determinować potęgę militarną państwa, które ten potencjał będzie potrafiło wykorzystać dla siebie, a nie przeciw sobie. Tymczasem liczba etnicznych Turków wynosi obecnie ok. $70 \mathrm{mln}$ i do 2050 r. może się zmniejszyć do 50 mln. W tym kontekście warto też wspomnieć o możliwym konflikcie wodnym w Górnej Mezopotamii, tj. między Turcją z jednej strony a Irakiem i Syrią z drugiej. Scenariusz takiego konfliktu został opracowany przez NATO w latach dziewięćdziesiątych ${ }^{25}$, przy czym działania zbrojne toczyłyby się w obrębie Kurdystanu.

Również porównanie przyrostu naturalnego populacji żydowskiej Izraela z populacją palestyńską jest niekorzystne dla tej pierwszej, co może determinować zaostrzanie się konfliktu palestyńsko-izraelskiego. Obecnie populacja Palestyny to $5 \mathrm{mln}$, podczas gdy Izraela $-8,5 \mathrm{mln}$, przy tym jednak $20 \%$ populacji Izraela to Arabowie, co powoduje, że obecnie proporcje te wynoszą ok. $7 \mathrm{mln}$ do $6,5 \mathrm{mln}$ na korzyść ludności żydowskiej, nie uwzględniając jednak kilkumilionowej diaspory palestyńskiej w innych krajach regionu. Współczynnik dzietności w Izraelu wynosi 3,04 i jest nieznacznie wyższy dla ludności arabskiej, a potencjał zwiększania populacji żydowskiej poprzez sprowadzanie jej spoza Izraela w dużej mierze się wyczerpał. Tymczasem współczynnik dzietności w Palestynie wynosi 4,13.

Niezrównoważenie przyrostu ludności w obrębie Bliskiego Wschodu sprzyja również zmianom proporcji między ludnością szyicką a sunnicką na korzyść tej pierwszej, co z uwagi na irański projekt geopolityczny budowy swojej potęgi regionalnej w oparciu o szyicką wspólnotę, a także iracko-irański konflikt o prymat w świecie szyickim może również determinować eskalację napięć i przeradzanie się ich w konflikt o charakterze militarnym.

\section{DEMOGRAFIA A TRYBALIZM W AFRYCE}

Inny, choć równie poważny charakter może mieć niezrównoważony przyrost naturalny w Afryce. Tu również może on prowadzić do transgranicznych konfliktów zbrojnych na dużą skalę, nie tyle jednak między państwami,

\footnotetext{
${ }^{25}$ Frederick LoREnz, Edward ERICKson, The Euphrates Triangle: Security implications of the Southeast Anatolia Project (Washington, D.C.: National Defense University Press, 1999), 47
} 
co między aktorami niepaństwowymi, tj. w szczególności plemionami oraz budowanymi w oparciu o nie organizacjami terrorystycznymi (przede wszystkim o charakterze dżihadystycznym). Sprzyjać temu będzie sztuczność i słabość afrykańskich państw, niestabilność wewnętrzna oraz korupcja. W państwach o zróżnicowanej strukturze plemiennej będzie to prowadzić do rozwoju konfliktów o władzę i trybalizacji podziałów politycznych. Można było to już zaobserwować na przykładzie kilku ostatnich wyborów w Kenii. Warto przy tym mieć świadomość wielkości transgranicznych plemion afrykańskich. Na przykład Fulani to już obecnie ponad 40-milionowa populacja, zamieszkująca kraje o rekordowych wskaźnikach determinujących przyrost naturalny. Inne wielkie plemię, Kanuri, liczy prawie $9 \mathrm{mln}$ osób i stanowi bazę dla terroryzującej północną Nigerię dżihadystycznej organizacji Boko Haram.

\section{PODSUMOWANIE}

Wysoki, a zarazem niezrównoważony przyrost ludności na Bliskim Wschodzie, połączony z niezdolnością państw do pokojowego zagospodarowania wynikającego $\mathrm{z}$ tego potencjału, będzie prowadzić do dalszych zaburzeń wewnętrznych, nowych „arabskich wiosen”, a także rywalizacji o potęgę. Można się zatem spodziewać nowych wojen domowych, zastępczych, a być może również międzypaństwowych konfliktów zbrojnych. W Afryce czynnikiem generującym konflikty będzie rywalizacja plemion połączona z dżihadystyczną agendą niektórych z nich. Dla Europy będzie to oznaczać wzrost niestabilności w najbliższym otoczeniu oraz dalszy napór zarówno uchodźców, jak i migrantów. Ponadto rosnące diaspory różnych grup etnicznych w Europie będą determinować przenoszenie konfliktów z Bliskiego Wschodu i Afryki do Europy, np. konfliktu turecko-kurdyjskiego, palestyńsko-izraelskiego, szyicko-sunnickiego czy afrykańskich waśni plemiennych.

\section{BIBLIOGRAFIA}

„Average marriage age in Iran increased by 3 years”. Tehran Times. Iran's Leading International Daily. Dostęp 27.12.2019. https://www.tehrantimes.com/news/424338/Average-marriage-agein- Iran-increased-by-3-years.

BiaŁoskórski, Robert, Łukasz Kiczma i Mirosław SuŁek. Potęga państw 2019. Rankingi potęgometryczne. Warszawa: Oficyna Wydawnicza Aspra-JR, 2019. DOI: 10.13140/RG.2.2.33929. 90722. 
Bialoskórski, Robert, Robert Kobryński i Mirosław SuŁek. Potęga państw 2017. Międzynarodowy uktad sit w procesie zmian. Raport potegometryczny. Warszawa: Oficyna Wydawnicza Aspra-JR, 2017.

„Egypt: Youth unemployment rate from 1999 to 2019”. Statista. Dostęp 27.12.2019. https:// www.statista.com/statistics/811968/youth-unemployment-rate-in-egypt./

„Global Firepower 2020”. GFP. Strench in Numbers. Dostęp 27.12.2019. https://www.globalfire power.com/.

KACZMARSKI, Marcin. Realizm neoklasyczny. W: Teorie i podejścia badawcze w nauce o stosunkach międzynarodowych, red. Ryszard Zięba, Stanisław Bieleń i Justyna Zając, 13-27. Warszawa: Wydział Dziennikarstwa i Nauk Politycznych Uniwersytetu Warszawskiego, 2015.

Koc, Ismet, Alanur CAVlin i Attila Hancioglu. „Demographic differentials and demographic integration of Turkish and Kurdish populations in Turkey". Population Research and Policy Review 27 (2008), no. 4: 447-457. DOI: 10.1007/s11113-008-9072-y.

Lorenz, Frederick, i Edward J. ERICKSON. The Euphrates Triangle: Security implications of the Southeast Anatolia Project. Washington, D.C.: National Defense University Press, 1999.

REPETOWicz, Witold. „Broń 'D' jako zagrożenie asymetryczne”. Wiedza Obronna 2018, nr 1-2 (262-263), 107-125.

Stoessinger, John G. The Might of Nations: World Politics in Our Times, $3^{\text {rd }}$ edition, New York: Random House, 1969.

SuŁek, Mirosław. „Globalny układ sił - stan obecny i kierunki ewolucji”. W: Studia nad geopolityka XX wieku, red. Piotr Eberhardt. Seria: Prace Geograficzne nr 242, 77-96. Warszawa: IGiPZ PAN, 2013.

SuŁeK, Mirosław. „O potęgonomii i potęgometrii”. Nowa Geopolityka. Dostęp 25.05.2020. https://geopolityka.net/o-potegonomii-i-potegometrii/.

SuŁek, Mirosław. Potęgometria. T. 1. Warszawa: Europejskie Centrum Analiz Geopolitycznych, 2017.

The World Bank. Data. Dostęp 27.12.2019. https://data.worldbank.org.

United Nations Development Programme. Human Development Reports. Dostęp 27.12.2019. http://hdr.undp.org.

Worldometer. Population. Dostęp 03.08.2020. https://www.worldometers.info/population/.

\author{
WPŁYW NIEZRÓWNOWAŻONEGO PRZYROSTU NATURALNEGO \\ W POEUDNIOWYM SASIEDZTWIE EUROPY \\ NA WYSTĘPOWANIE KONFLIKTÓW WEWNĘTRZNYCH I REGIONALNYCH
}

Streszczenie

Przyrost ludności na Bliskim Wschodzie i w Afryce jest nie tylko większy niż w Europie, ale również niezrównoważony w wymiarze regionalnym. Oznacza to, że proporcje populacji w odniesieniu do poszczególnych państw, a także grup etnicznych, religijnych i plemiennych, podlegają procesowi poważnych zmian i ta tendencja będzie kontynuowana w najbliższych dekadach. Ponieważ populacja jest fundamentalnym elementem potęgi państw, będzie więc miała nie tylko konsekwencje wewnętrzne, ale też wpływ na układ geopolityczny. Gwałtowny przyrost ludności może z jednej strony osłabić i zdestabilizować niektóre państwa, jeśli ich rządy nie będą zdolne do odpowiedniego nim zarządzania, zwłaszcza w zakresie zatrudnienia. Populacja może być również wykorzystana do regionalnej rywalizacji, zagrożenia innych państw strumieniem migracyjnym, 
a także wyzwań o charakterze militarnym. Wpływ niezrównoważonego przyrostu ludności na Bliskim Wschodzie na regionalną stabilność nie napawa optymizmem. Najprawdopodobniej będzie on prowadził do nowej regionalnej rywalizacji według podziałów sektariańskich i etnicznych, a także geopolitycznej rywalizacji poszczególnych państw o potęgę. Przyrost ludności dwóch spośród trzech najludniejszych państw regionu, tj. Turcji i Iranu, szybko spada. Jest to ważne również dlatego, że te państwa pretendują do roli mocarstw regionalnych. $\mathrm{Z}$ drugiej strony największy przyrost ludności na Bliskim Wschodzie występuje w Iraku, który jest uważany za państwo słabe, o ile nie upadłe. Nierozwiązane problemy etniczne, w szczególności kwestia kurdyjska i palestyńska, dodatkowo przyczynią się do niepewności co do perspektywy stabilności i prawdopodobieństwa eskalacji starych konfliktów, zwłaszcza że przyrost ludności wśród tych grup jest wyższy niż w regionie. W Afryce niezrównoważony przyrost ludności może powodować konflikty plemienne. Bliskość Europy i wysokie prawdopodobieństwo migracji z obszarów objętych konfliktami powoduje, że niezrównoważony przyrost ludności i jego konsekwencje na Bliskim Wschodzie i w Afryce będą również wyzwaniem dla stabilności oraz bezpieczeństwa Europy.

Słowa kluczowe: przyrost ludności; Bliski Wschód; Afryka; geopolityka; rywalizacja o potęgę; niestabilność; sektarianizm; problemy etniczne.

\section{IMPACT OF UNBALANCED POPULATION GROWTH \\ IN THE SOUTHERN NEIGHBORHOOD OF EUROPE ON THE OCCURRENCE OF INTERNAL AND REGIONAL CONFLICTS}

\section{Su m mary}

The population growth in Middle East and Africa is not only much bigger than in Europe but also regionally unbalanced. This means that the proportions of this macroregion population with regard to the various states as well as ethnic, tribal and religious groups are in the process of a significant change and it will be continued in the nearest decades. As population is a fundamental element of the states power it will have not only internal consequences but also geopolitical impact. Rapid population growth on one hand may weaken and destabilize some states if its governments will not be able to properly manage it, especially with regard to employment. But population may also be used to project power in regional rivalry, threaten other states with migration flow as well as to challenge other countries militarily. The impact of unbalanced population growth in Middle East on regional stability and security do not seems very optimistic. Most probably it will lead to new regional competition along sectarian and ethnic lines and geopolitical rivalry among the states of this region. The population growth of two of the three countries with biggest population in this region, namely Turkey and Iran, is quickly declining. This is important also because these countries aspire to the role of regional powers. On other hand the country with the biggest population growth in Middle East is Iraq that is widely considered a weak if not failed state. Unsolved ethnic problems, especially Kurdish and Palestinian issue, will add up to the uncertainty of stability and probability of escalation of old conflicts, especially as the population growth among these ethnic groups is higher then average in the region. In Africa unbalanced population growth may cause tribal conflicts. Proximity of Europe and high probability of migration from conflict zones makes the issue of unbalanced population growth and its consequences in Middle East and Africa a challenge also for European stability and security

Key words: population growth; Middle East; Africa; geopolitics; power competition; instability; sectarianism; ethnic problems. 